\title{
Municipality's financial potencial and policy of flood risk management in Poland
}

\author{
Grzegorz Dumieński ${ }^{1,}$, Marcin Krzyżanowski $^{1}$, and Andrzej Tiukało ${ }^{1}$ \\ ${ }^{1}$ Institute of Meteorology and Water Management - National Research Institute, Wroclaw Branch 51- \\ 616 Wroclaw, ul. Parkowa 30, Poland
}

\begin{abstract}
For Polish municipalities - basic units of local government (LGU), flood constitutes a significant source of material losses resulting both from flood damages and from the costs of restoring the regular functioning of the municipalities after the disaster is gone. Authors stated a thesis that the municipality, despite its constitutional obligations connected with providing the safety for its citizens, is not capable to bear the financial burden shaping the flood protection system in the basin. It is, however, due to support the flood protection system by strengthening its adaptive potential and adaptive capacity for efficient limitation of adverse consequences of flood. To justify this thesis, the financial condition of the municipalities threatened with flood was compared to the size of potential flood losses for floods of the medium probability of occurrence $(p=1 \%)$. Authors have shown that the municipality's structure, more than its budget size decides about its financial potential. Especially the municipality's own revenue is an evidence for the determined financial potential, at the same time, it can be a source of the undertaken actions in order to increase the level of the municipality's adaptability in the context of flood hazard. Conducted analyses allow to shape the flood risk management policy, both at the municipal level and on a national scale.
\end{abstract}

\section{Introduction}

The flood is one of examples of a natural threat which may constitute a source of adverse consequences in a given analytical unit. In Poland it can be, among others, the municipality being a basic local government unit (LGU) [1]. Every year the phenomenon of flood causes huge losses around the world, both in lives and health of people, as well as the material losses [2]. In Poland last big floods were in 1997 and 2010 [3, 4]. The predicted climate changes assume the increase of the frequency and strength of the occurrence of the meteorological-hydrological phenomena, including floods $[2,4,5]$.

\footnotetext{
* Corresponding author: grzegorz.dumienski@imgw.pl
} 
The municipality's constitutional duties include, among others, satisfying the local community's basic needs - also in the context of providing safety for its citizens. In this aspect, the crisis management, at the level of the basic LGU, will mean the management of the municipality's adaptation process to identified and predicted threats in the future. It's objective is the adequate response in case of the disaster occurrence and after its end, as well as the municipality's quick back to its stable operation, i.e. to achieve its intended goals [3]. Eventually, the objective of the municipality's undertaken adaptive activities towards flood hazard can be brought to limit the adverse consequences of the disaster.

The aim of the article is to confirm the thesis that in the light of potential flood losses of the Polish municipalities, including their limited financial potential, the share of the basic LGU in shaping of the flood protection system should be limited to planning and implementation of the effective process of their adaptation to the identified and predicted flood hazard in the future. Therefore, an auxiliary question is: can information on the size of the municipality's own revenue be useful for assessing the municipalities' ability to deal with the flood hazard?

\section{The financial potential of the municipality and its adaptability}

The financial potential, beside the human capital and social potential, as well as: ecological and organizational potentials, is one of the determinants, that with no doubt defines the municipality's adaptability [6]. It is defined as the ability to obtain the financial resources and their effective use in order to implement own intentions (objectives), including reduction of flood risk $[6,7]$.

It should be emphasized that the local government finances are designed to cover the needs of local communities, including a special budget reserve dedicated to crisis situations [8]. The legislator stipulated that the budget expenditure of the local governments must first provide the continuous and uninterrupted performance of own mandatory tasks, and subsequently provide operation of all the bodies [9]. That is why the own income in the structure of the municipality's budget is so important, because its amount proves not only about the efficiency of tax collection, but also about the attractiveness of a given municipality, its openness to industry, services, etc.

Municipal expenditure is divided into current and property expenditure. The size of property expenditure in the commune's budget depends on the level of its own income or on covering investment liabilities with these revenues. Property expenditure is not obligatory as it is current, which means that in a difficult financial situation, the municipality may resign from their implementation.

Analysis of the municipality's expenditure structure allows you to assess its financial condition. The relation between current and property expenditures indicates the rate and possibilities of the commune's development, and thus its ability to achieve the main goal of achieving social progress including the sustainability of the ecological system.

In case of the municipality where current expenditure dominates on the property expenditure to a large extent, it means that this unit has low income on its own, and therefore after performing obligatory current payments, does not possess enough assets for property expenditure aimed at, as the name suggests, increasing its material resources [10].

Thus the municipality's own revenue decreased by the cost of servicing public debt is the only available source of covering the costs of the adaptation activities planned to increase its resilience to the flood hazard. 
Therefore the municipality's own revenue, decreased by the cost of servicing public debt, mainly shows its financial potential. Published in 2015 maps of flood risk and flood hazard (Polish abbr. - MRP and MZP) include, among others, the information on the size of potential flood losses in municipalities. Comparison of those losses with the municipalities' revenues, especially with the own ones, can constitute a useful information, helpful in creating flood risk management policy in Poland [11], both for the local governments and for the state authorities. Because it says about financial abilities to deal with the flood hazard by the basic LGU.

\section{Materials and methods}

In order to confirm the assumed research hypothesis, for the municipalities threatened with flood, with medium probability of occurrence $p=1 \%$ (the so-called 100 year flood), the size of potential flood losses have been determined [12]. Then, on the basis of the Local Data Bank (LDB), the information on the amount of total of the municipalities was obtained, as well as on the amount of own revenues and the cost of servicing the public debt in the financial year 2016. The collection of the above information allowed to prepare the spatial distribution of 1305 municipalities threatened with 100 year flood, characterized by the following variables:

1. The size of potential flood losses in the municipalities [millions of PLN]

2. The size of the municipalities' own revenues decreased by servicing public debt in 2016 [millions of PLN]

3. The share of percents of the municipality's own revenues decreased by servicing public debt in its total revenues in 2016 [\%]

4. The ratio of the municipality's potential flood losses to its own revenues decreased by the costs of servicing public debt in 2016 [-]

and ordered in five equally numerous collections (separated by quintiles of the analyzed variables).

\section{Results and discussion}

Spatial distribution of the municipalities in Poland according to the size of potential flood losses caused by the 100 year flood was presented in the figure. 1. This indicator was previously presented in the works $[3,6]$, however, for the needs of those analyses it has been updated including changes of ranges of flooding introduced in MRP, 1\% (100 year flood) and changes in the administrative division of Poland (concerning fusion of some municipalities, change of their names, etc.) [1]. The amount of potential material losses in particular municipalities was calculated in accordance with the Regulation [12]. Presented data do not include losses resulting from the failure of the embankments and disaster of hydrotechnical devices. Underestimated amount of those losses calculated in accordance to the Regulation results from the lack of indexation of the rates included in the regulation since its publication in the official journal $[3,13]$, the more so, that the starting materials for this regulation were developed in 2010. It needs to be emphasized that it falsifies the picture of potential direct material effects of flood in Poland, the more so, that it does not either include the municipalities' losses resulting from the costs of conducting the rescue action during floods and costs of restoring the normal functioning of the municipality after the flood ceases $[3,7,13]$. 


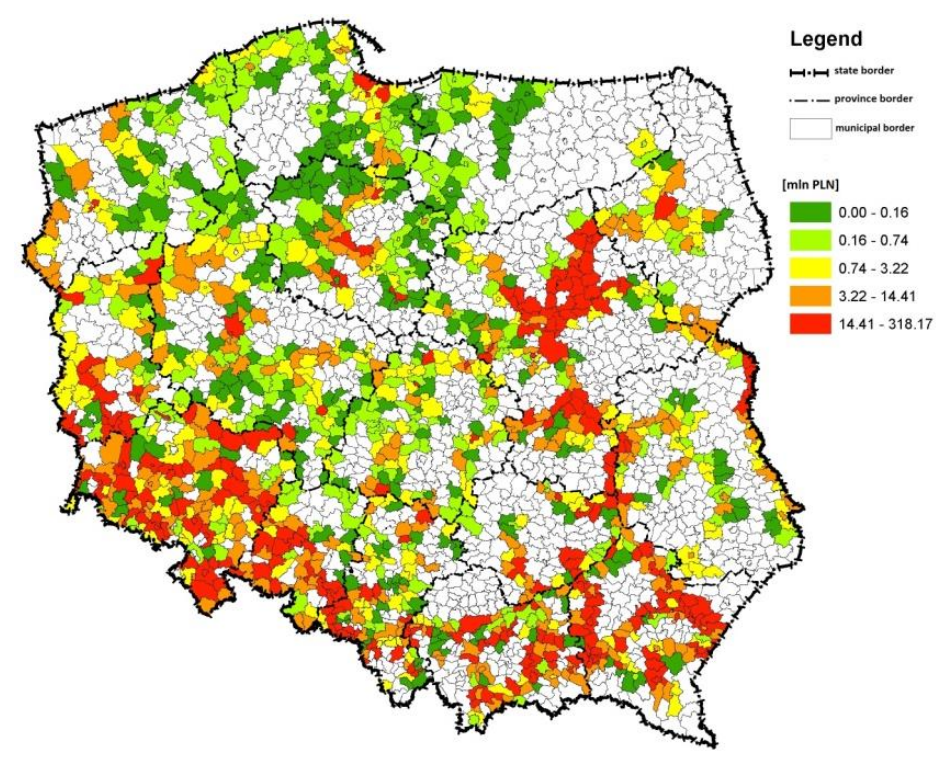

Fig. 1. Spatial distribution of the municipalities in Poland by the size of potential flood losses [source: own work based on the ISOK project data].

The amount of the municipalities' flood losses in Poland, calculated for the 100 year flood, based on the available maps of the flood hazard and flood risk, contains between 10 thousand PLN and 318.17 million PLN, while the values of particular quintiles of empirical distribution of the amount of flood losses in the municipalities, are respectively: $0.16,0.74$, 3.22 and 14.41 million PLN. The biggest potential flood losses are recorded in the municipalities located in the areas of particular flood hazard, in the upper and middle course of the rivers Oder and Vistula (two major rivers of Poland) and their river basins. It is also worth indicating that in $60 \%$ of the Polish municipalities threatened with flood, potential flood losses are not bigger than 3.22 million PLN. While in the subsequent $20 \%$ of municipalities threatened with 100 year flood in Poland, potential flood losses are included within the range from 3.22 million to over 14,41 million PLN. The municipalities with the biggest potential flood losses are: Lubomia (318.17 million PLN), Wyszków (280 million PLN), Kędzierzyn-Koźle (250 million PLN) and Warszawa (200 million PLN). It is worth emphasizing that in approximately 35 municipalities in Poland, potential flood losses are over 100 million PLN. On the other hand, the average level of potential flood losses in the municipalities, in the area of which a special zone of flood threat was designated on the maps of flood hazard and flood risk is 12.5 million PLN, which indicates the right asymmetry of the frequency (frequency) curve of the random variable - the amount of potential flood losses of the municipalities, in case of the occurrence of the 100 year flood. 


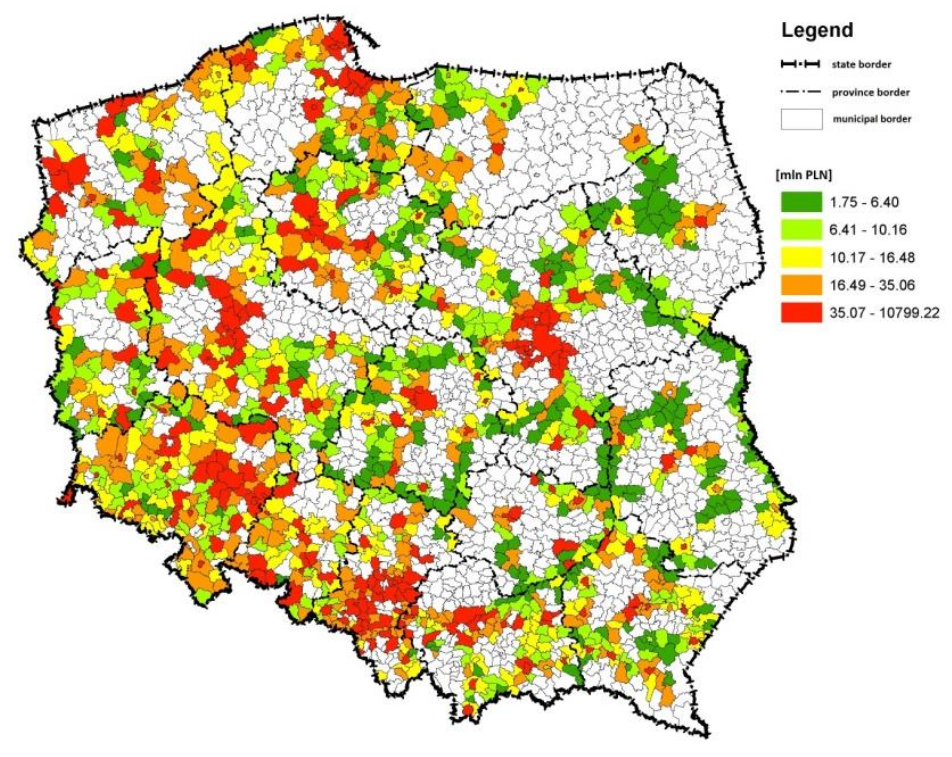

Fig. 2. Spatial distribution of municipalities in Poland in accordance with their own revenue in total, decreased by the cost of servicing public debt [million PLN] [source: own work based on data from LDB].

The second analyzed variable characterizing the municipality threatened with flood is the amount of its own revenue in total, decreased by the cost of servicing public debt [million PLN]. The spatial distribution of Polish municipalities, according to this indicator, is presented in the figure 2. The amount of the municipality's own revenue decreased by the cost of servicing public debt in Poland includes between 1.75 million PLN and 10799.22 million PLN, while the values of particular quintiles of the empirical distribution of this random variable is respectively: 6.40, 10.16, 16.48 and 35.06 million PLN. It needs to be emphasized that $80 \%$ of all municipalities threatened with 100 year flood have own revenue decreased by the cost of servicing public debt at the level of up to 3 million PLN. In the last class, the municipalities were qualified according to their revenue reaching from approximately 35 million PLN to over 10.8 billion PLN (Warsaw), with the cost of servicing its public debt being over 230 million PLN. Summing up, the highest own revenue, corrected by the cost of servicing public debt occur in large cities: Warsaw 10.8 billion, Cracow (approx. 3 billion), Wrocław ( 2.7 billion), Łódź (2.4 billion) and Poznań ( 2 billion). While the lowest were recorded in small country municipalities mostly located in the eastern Poland, where they achieve own revenues at the level of 2 million PLN, including the cost of its debt [more: 14]. 


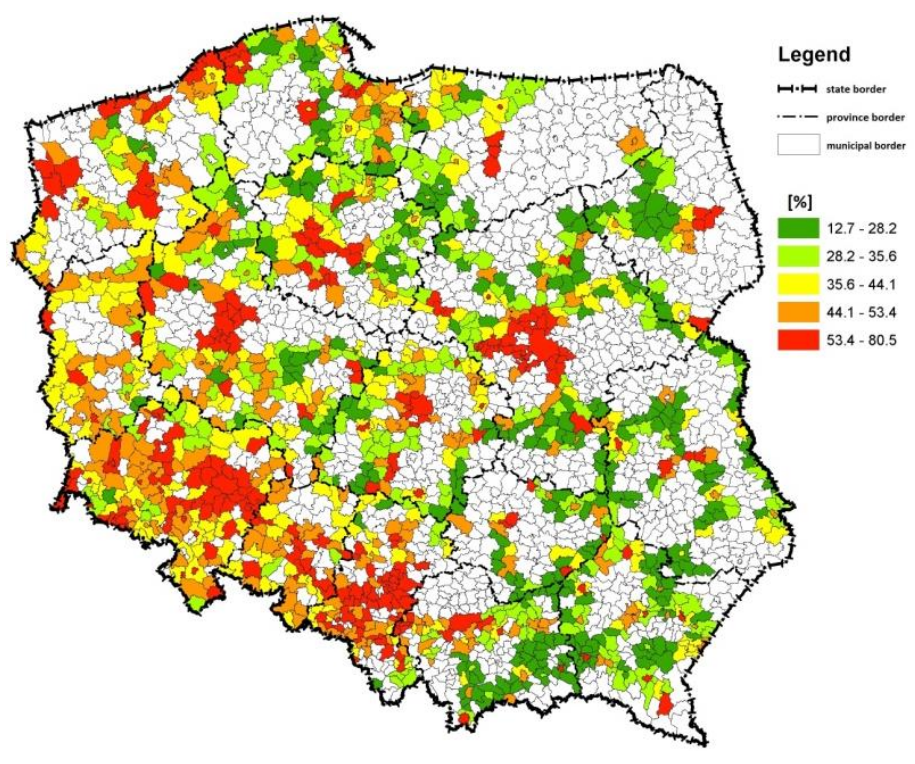

Fig. 3. Spatial distribution of Polish municipalities according to their own revenue decreased by the cost of servicing public debt in municipal revenue in total, in 2016 [\%] [source: own work based on data from GUS and ISOK project].

In the figure 3 spatial distribution of Polish municipalities was presented, according to the percentage share of their own revenue, decreased by the cost of servicing the public debt, in the municipal revenue in total, in 2016. In assessing the level of municipality's adaptability to identified hazards, the information coming from this indicator is highly significant. It shows the autonomy of the municipality in opportunities for realization of objectives it determined and becoming independent from state's subsidies. The bigger share of own revenue in the municipal budget in total, the bigger is its liberty in setting the objectives of the municipality and shaping future expenditure.

The percentage share of own revenue in the municipal revenue in total ranges from approximately $12 \%$ in the municipalities: Koło, Świdwin, Radgoszcz, to over $80 \%$ in the municipality Kobierzyce (one of the richest municipalities in Poland). The values of particular quintiles of the empirical distribution of this random variable are respectively: 28.2, 35.6, 44.1 and 53.4\%. The average value of this indicator is for the Polish municipality $40,8 \%$. Worth emphasizing is the remark that the most municipalities which value of own revenue, decreased by the servicing of public debt to the budget in total is within $50-80 \%$ of those located in the southern and western Poland and in the Masovian province. 


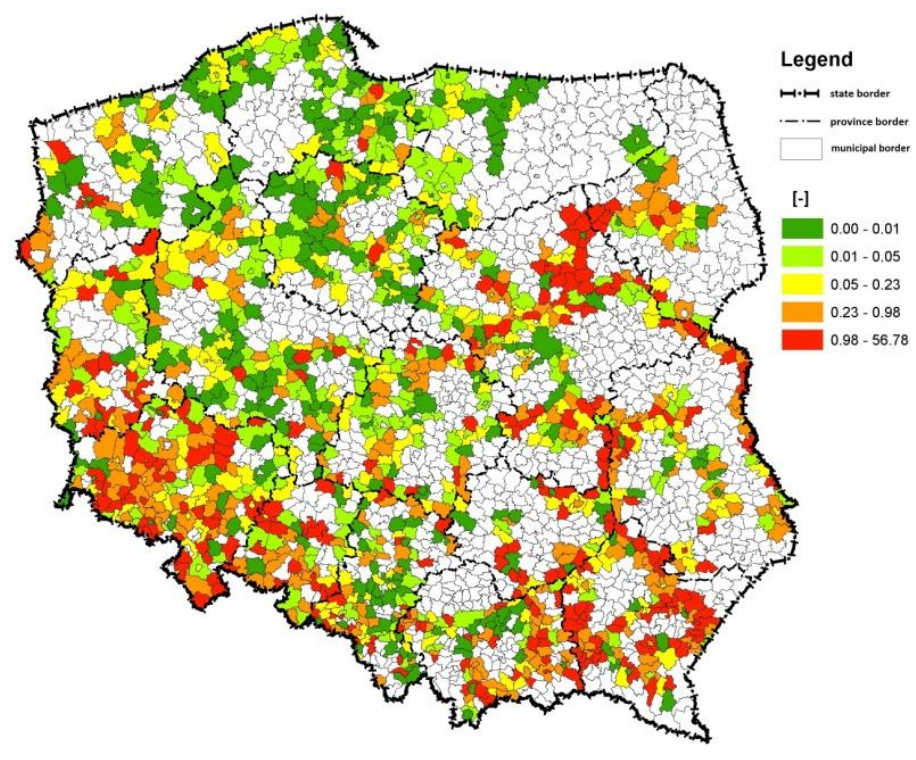

Fig. 4. Spatial distribution of Polish municipalities according to the ratio of their potential flood losses to the municipality's own revenue in the financial year 2016, decreased by the cost of servicing public debt [source: own work based on data from GUS and ISOK project].

Because mutability of the percentage share of own revenue in the municipality's revenue in total is very high, it was assumed that the most significant variable characterizing the municipalities threatened with flood is the variable describing the ratio of potential flood losses to its own revenue decreased by the costs of servicing public debt. The figure 4 presents then the spatial distribution of Polish municipalities according to the ratio of their potential flood losses to the municipality's own revenue in the budget year 2016, decreased by the cost of servicing public debt. The authors assume that this variable characterizing the municipality, well characterizes its economic vulnerability to the flood hazard, because it collides the amount of potential flood losses of the municipality with the amount of funds which the municipality can freely dispose in case of flood disaster. The values of particular quintiles of the empirical distribution of this random variable are respectively: $0.01,0.05,0.23$ and 0.98 . On the basis of the quotient distribution of potential flood losses and its own revenue decreased by the costs of servicing public debt, we can conclude that the share of potential flood losses in the municipality's own revenue decreased by the cost of servicing public debt, in more than $60 \%$ of them it is lower than $23 \%$ of their own revenue. There are also municipalities which potential losses constitute the multiple of own revenue of those units. The problem concerns mainly small rural municipalities located in the areas of particular flood threat, along the rivers Vistula and Oder and their basins (the Kodeń municipality - flood losses exceed own revenue 55 times). In more than $40 \%$ cases of 1305 municipalities threatened with 100 year flood, potential flood losses balance with the municipalities' own revenue (including costs of servicing public debt). What is important, averaging the value of observation, the ratio of potential flood losses to the municipality's own revenue decreased by the servicing of public debt is 1.02 (it means that the losses exceed the municipality's total own revenue). It is an information that constitutes the basis for the critical assessment of the adaptive 
potential of Polish municipalities threatened with flood and the role of the municipality which it is supposed to play in the flood protection system.

\section{Conclusions}

The material presented in this article provides relevant information on the financial condition of Polish municipalitys in relation to the potential material flood losses for floods with a medium probability of occurrence. The elaboration proposes four variables characterizing the municipalitys threatened by floods which are useful to classify them according to the size of the potential flood losses and also according to their financial potential which may be directed to the effective preparation against the threat, for responding in a situation of disaster and for taking the necessary action after it is over. The authors considered as justified the conclusion, that the financial condition of Polish municipalitys against the size of the potential flood losses is very low. Especially useful in this assessment is the spatial distribution of municipality's in Poland according to the ratio of their potential flood losses to the municipality's own revenue in the budget year 2016 less the servicing cost of the public debt. It can also be recognized that figure 4 illustrates the spatial distribution of municipalitys according to their economic susceptibility to the risk of flood.

The carried out analyses allow to confirm the point, that the amount of potential flood losses of municipalitys in Poland is so large in relation to their own incomes that the participation of communes in shaping the flood protection system should be limited to planning and implementing the effective adaptation activities adequate to the identified and anticipated risks of flood in the future. Municipality's, as the basic local government units in Poland, should strengthen their resistance to flood threads by increasing the human capital and social potential of the municipality's inhabitants and increasing their financial, ecological and organizational potential [7].

The role of state should be, however, to shape the flood protection system in the range of drainage and river basin. It should be emphasized that the Flood Risk Management Plans (Polish abbr. - PZRP), adopted by the Polish government for river basins and water regions include, among others, plans for redistribution of funds foreseen for the extension of the flood protection system which reduce the identified risk of flood [15]. The authors recognize that the state policy of flood risk management, understood as a sequence of specific decisions and actions (or their absence) [11], should not only focus, as till now, on shaping of the even more effective flood protection system but also on creating an effective material and organizational system of assistance to communes in a situation when the losses caused by the flood are in a such scale that the communes will not be able to cope independently to eliminate them. An important role of the state should be to create incentives for communes to undertake adaptation activities according to changes of the climate which may result in the appearance of increasingly violent and dangerous weather phenomena. A good example of this type of state administration activity is the initiation and implementation by the Ministry of the Environment of the project "Development of Urban Adaptation Plans for cities with more than 100.000 inhabitans in Poland".

This work was financially supported by Development of Urban Adaptation Plans for cities with more than 100.000 inhabitans in Poland (Polish abbr. - MPA). The project is financed by the European Union from the Cohesion Fund and the state budget as part of technical assistance for the Infrastructure and Environment Program 


\section{References}

1. Ustawa z dnia 8 marca 1990 r. o samorządzie gminnym (Dz.U. z 2017 r., poz. 1875) (2017)

2. S. N. Jonkman. Nat. Hazard, 34, 2 (2003)

3. G. Dumieński, A. Pasiecznik-Dominiak, A. Tiukało [in:] K. Piekarska, A. Kotowski, B. Kaźmierczak (eds.), (Oficyna Wydawnicza Politechniki Wrocławskiej,2015)

4. M. Wdowikowski, B. Kaźmierczak, O. Ledvinka. Meteorol. Hydrol. Water Manage., 4, 1 (2016)

5. K. Li, S. Wu, E.Dai, Z. Xu. Nat. Hazards, 63, 7 (2012)

6. M. Krzyżanowski, A. Tiukało. Gospodarka Wodna, 2017, 4 (2017)

7. G. Dumieński, A. Lisowska, A. Tiukało. Misc. Geographica, (to be published)

8. P. Felis. Business and Economic Horizons, 10, 3 (2014)

9. B. Z. Filipiak. Finanse, Rynki Finansowe, Ubezpieczenia, 1, 79 (2016)

10. I. Muller-Frączek, M.B. Pietrzak. Acta Universitatis Nicolai Copernici, 2009, 391 (2009)

11. G. Dumieński, A. Lisowska, M. Bedryj, A. Tiukało [in:] R. Sadowski, Z. Łepko (eds.), (Wydawnictwo Naukowe Franciszka Salezego, Warszawa, 2017)

12. Rozporządzenie Ministra Środowiska, Ministra Transportu, Budowsnictwa i Gospodarki Morskiej, Ministra Administracji i Cyfryzacji oraz Ministra Spraw Wewnętrznych z dnia 21 grudnia 2012 r., w sprawie opracowania map zagrożenia powodziowego oraz map ryzyka powodziowego (Dz. U. z 2013 r. poz. 104) (2013)

13. I. Godyń. Gospodarka w Praktyce i Teorii, 1, 38 (2015)

14. J. Sokołowski, [in:] S. Owsiak (ed.) (Wydawnictwo Akademii Ekonomicznej w Krakowie, 2004)

15. M. Krzyżanowski, A. Tiukało [in:] B. Kaźmierczak, A. Kotowski., K. Piekarska (eds.), (Oficyna Wydawnicza Politechniki Wrocławskiej, 2016) 